\title{
LEGAL PROTECTION OF INVENTION IN THE FIELD OF BIOINFORMATICS IN INDONESIA AND SINGAPORE
}

\author{
Abdul Atsar \\ Faculty of Law,University Singaperbangsa \\ Karawang, Indonesia \\ abdul.atsar@staff.unsika.ac.id- \\ abdulatsar.fhunsika@gmail.com
}

\begin{abstract}
The positive impact of globalization, the increasing progress of science and technology, such as biological science and information technology. The advancement of science and technology will give birth to creative people who can produce innovative products, such as in the field of bioinformatics so they need legal protection for their work or invention through legal protection system of Intellectual Property Rights. The method of writing this research is normative juridical. The approach of this research is the approach of legislation, conceptual, and comparative. This research includes descriptive research. In this research, used primary data source and secondary data source. Data analysis technique is qualitative normative analysis technique. Software, databases, methodologies and bioinformatics products can only be protected through the copyright regime, this is based on the provisions of Law no. 28 of 2014 on Copyright, Article 40 paragraph (1). A software can still be protected by a Patent mechanism if the software related to the computer program can solve technical problems and related to technology and there is already patent protection from the country of origin. Law no. 13 of 2016, Article 4. Only bioinformatics hardware, patented. In addition, bioinformatics (information) methodologies and products (information) can be protected through a trade secret regime.
\end{abstract}

It is stipulated in the provisions of Article 1 number 1 and Article 2 of Law no. 30 Year 2000. Singapore governing Patents is a Patent Act (Chapters 221, Sections 42, 110 and 115) may be given for the discovery of a product or process. The invention shall meet the following conditions: 1) new; 2) inventive step; 3) Applicable in industry;

4) The publication or exploitation of the invention is generally not expected to encourage violent, immoral or anti-social behavior; Bioinformatics may be protected by Patents if they meet these four conditions. The law governing patent protection in Singapore when compared to Law No. 13 of 2016, has similarities regarding its patentability and protection terms, patent subjects, legal remedies and other types of patents.

\section{Keywords-----Legal Protection, Bioinfor- matics, Indonesia, Singapore.}

\section{INTRODUCTION}

Globalization brings impacts on human life, among the positive impacts of globalization, namely the advancement of science and technology, such as biological science and information technology. With these advances will give birth to creative people who can produce innovative products that require legal protection of their work or invention through legal protection systems of Intellectual Property Rights over the invention that it produces. 
Recognition of the results of knowledge, art and culture is accommodated through the granting of exclusive rights to inventors, namely the recognition of intellectual property rights (IPR). Indonesia has been regulated through various laws. Various arrangements on Intellectual Property Rights through Law Number 7 of 1994 on Ratification of Agreement Establishing the World Trade Organization. In an effort to protect the inventor has been issued Act of the Republic of Indonesia Number 14 Year 2001 or Number 13 Year 2016 regarding Patent.

The granting of a patent by the state to an inventor aims to provide incentives to the inventor, with the aim that the stimulus may stimulate other new discoveries or the development of the prior inventions of the same person or from others. New discoveries that are then carried out will inevitably bring progress to society in the form of advances in science and technology, which will make people more prosperous. On the other hand, it is intended that the general public at any one time, may benefit from the findings of the invention by carrying out its own invention without obtaining a license or providing counter-performance to the patent holder.

Indonesia already has Patent related law, that is Law No. 14 Year 2001 or Number 13 Year 2016 on Patent. The field of bioinformatics is a very important field for developing countries such as Indonesia, considering the bioinformatics data generated from a study can be a genetic resource or germplasm belonging to Indonesia. Bioinformatics is a science that studies the application of computational techniques to manage and analyze biological information. This field includes the application of mathematical, statistical, and informatical methods to solve biological problems, especially by using DNA and amino acid sequences and related information. Examples of key topics of this field include databases for managing biological information, alignment sequence alignment, structural prediction for predicting the structure of proteins and secondary structures of RNA, phylogenetic analysis, and gene expression analysis.

Bioinformatics is a science that studies the application of computational techniques to manage and analyze biological information. Currently, research in the field of bioinformatics has produced enormous data in the form of genome sequences. Generally bioinformatics data are not published in traditional literature, but are first made available on the internet for free or free access by the public, for example "raw data" from the human genome sequence project on the Sanger Center site (www.sanger.ac.uk / HGP / Sequence/).

The collection and interpretation of all this information requires a new approach in the field of biology so that a new discipline called bioinformatics, which combines the disciplines of mathematics, computer science and biology with the primary aim of understanding the "biological meanings" of various data to include data entry, , analysis and interpretation of biological information using computers. Although bioinformatics "free data" is freely available (free) on the Internet, but to get the "meaning" of "raw data" requires special "expensive" skills because the analysis and interpretation of the raw data available on the Internet will produce "data mature "or" valuable information "of high economic value to do business. Therefore, such "raw or valuable information" typically has a protected intellectual property value, either through a Patent or copyright regime. Intellectual property in bioinformatics can include three things: 1) bioinformatics tools such as software algorithms, database architectures and hardware; 2) the methodology involved in the capture and interpretation of data from biological sources; 3) products of research in the form of "information" of high 
economic value because it can be used to conduct business.

The Patent Law provides legal protection against invention in the field of bioinformatics in the form of process and product. Patents are awarded for the work or idea of invention in the field of Bioinformatics, in the form of bioinformatics hardware. Patents are awarded to the work or ideas of invention in the field of technology, which after being processed can produce a product or just is process only, then if didayagunakan will bring economic benefits as well. This is what gets legal protection. By itself legal protection is not given automatically, there must be a previous application.[1]

Starting from the background description of the problem above, then it can be formulated the following problem: how to protect the law of invention in the field of bioinformatics in Indonesia and in Singapore?

\section{RESEARCH METHODS}

The research approach used in this research is normative juridical. Normative juridical research is a scientific procedure to find truth based on the logic of science from the normative side whose object is the law itself. In this study, law is seen as a rule of law according to the doctrine of positivism flow in the science of law.[2] This research is done through three approaches: statute approach, conceptual approach and comparative approach. This research is a descriptive research that aims to describe something in a particular place and at a certain moment.[3] In this study, secondary data sources are used, which include:

a. Primary legal materials, namely binding legal materials, comprising legislation, jurisprudence, and treaties. The primary legal materials used in this study are national legislation and international agreements in the field of Intellectual Property Rights (IPR), specifically in the field of Patents such as the Law on
Patents namely Law no. 13 of 2016 and various relevant legislation.

b. Secondary legal material, ie all legal materials that provide explanation of the primary legal material. Includes journals, reference books, scholarly works of scholars, scientific research results that examine the legal issues studied by incorporating other social sciences. Legal material The secondary ones are mainly legal books including thesis, and dissertation law, explanation of the Law and legal journals.[5]

c. Tertiary legal material, namely all legal materials that provide guidance / explanation of primary and secondary legal materials. Includes materials from internet media, dictionaries, articles on journals or newspapers.

In this study the authors use the technique of collecting data with literature study through cataloging first in the form of data collection through library research by looking at a list that provides information about the collection owned in a library.[7] Then study the books / literatures related to the titles and problems discussed in this study. In addition to literature study, this research is also conducted through cyber media, namely by searching for information and news about the problems related to this research via the internet.

Data analysis technique is done by way, the data obtained will be analyzed descriptively normative qualitative. The data obtained from bibliography search, analyzed by describing thoroughly the subject matter and analyzing the data according to the quality and correctness then connected with the theory obtained from bibliography research and the applicable legal provisions such as law and regulation, so that obtained the answer to the problem posed. The conclusions are drawn by using deductive way of thinking that is the fundamental way of thinking to the things that are general and then drawn conclusions that are specific in accordance with the subject matter. After the data 
analysis is complete, then the results will be presented descriptively, that is by telling and describing what it is in accordance with the problems studied. From these results then drawn the conclusion that is the answer to the problems raised in this study.

\section{RESULTS AND DISCUSSION}

A. Regulation of Legal Protection Against the Invention in the Field of Bioinformatics in Indonesia

Patents in Indonesia shall be governed by Law Number 13 Year 2016 regarding Patents. Prior to applying for a Patent, it is strongly recommended that the inventor first perform the search, to get an idea of whether the proposed invention does meet the requirement of novelty, meaning that there has never been any prior disclosure by anyone, including the inventor himself.

Searches may be made to Patent documents whether stored on DJKI database, or other representative offshore Patent offices as well as relevant to the technology of the invention to be Patented; and also to non-patent documents such as related scientific journals.

Patent Search is even strongly advised to do before a research plan on a technology is implemented, in order to perform technology mapping based on available Patent documents, so that research can be done more effectively and efficiently. After a search and it is believed that the patented invention will still contain novelty, the next step is to create a Patent specification, consisting of at least the following:

a. Title of Invention;

b. The Background of the Invention, which describes the existing technology and the problems contained in the technology, which the invention attempts to overcome;

c. The Brief Description of the Invention, which briefly describes the features contained in, and composes, the invention;

d. A Complete Description of the Invention, which explains how to carry out the invention;

e. Technical drawings, if necessary to explain the invention more clearly;

f. Brief Description of the Drawings, to describe the included Technical Drawings;

g. Abstract, a summary of the invention in one or two paragraphs;

h. The claim, which provides restrictions on which features are declared inventive and inventive by the inventor, is therefore eligible for a patent.

Preparation of Patent specifications requires expertise and experience of its own, because it needs to combine the language of engineering and legal language in it. Many Registered IP Consultants have the qualifications of such expertise and experience, and will be able to assist you in developing the Invention Specifications. The Patent Specification is one of the minimum requirements that must be included in applying for a Patent to be granted an Admission Date, in addition to a completed and fourfold Application Form, and paying a Patent Application fee of Rp. 750.000,00. If these three minimum requirements are met, then the application will receive the Filing Date. Another requirement of formality requirements may be completed for three months from the Filing Date, and may be renewed twice, respectively for two and one month. The requirements of the formalities are:

a. Statement of Right, which is the statement of the Patent Applicant that he does have the right to file the Patent application;

b. Letter of Transfer of Rights, which is evidence of transfer of right from the Inventor to the Applicant of Patent, if the Inventor and the Applicant are not the same person;

c. Power of Attorney, if the application is filed by a Proxy; 
d. Copy of ID / Identity of the Applicant, if individual Applicant;

e. Photocopy of Legal Entity Establishment that has been legalized, if the Applicant is a Legal Entity;

f. Copy of NPWP of Legal Entity, if the Applicant is a Legal Entity; and

g. Photocopy of Identity Card / Identity of person acting on behalf of the Applicant of Legal Entity to sign the Statement and Power of Attorney.

After the examination period has passed and all formalities are declared complete, the next step is Announcement. The announcement period will commence immediately after 18 (eighteen) months elapsed from the Filing Date, and will last for 6 (six) months. Entering this

announcement period the Patent application will be published in the Official Patent Gazette and other official media of Patent announcement. The objective is to open the opportunity for the public to know about the invention being filed a Patent, where the public may file a written objection to the Director General of Intellectual Property (DJKI), if the public is aware that the invention is not eligible for patent. As soon as the announcement period ends, or no later than 36 (thirty six) months from the Filing Date, the applicant may submit Substantive Examination Application by submitting completed Form and pay the fee to the Director General of Intellectual Property (DJKI). If the applicant does not file a Substantive Examination Application within the time limit of 36 months from the Filing Date, then his application will be deemed withdrawn and thus his invention becomes a public domain. In the Substantive Examination Phase, the Director General of Intellectual Property (DJKI) through the Patent Examiner will determine whether the invention for which the patent has fulfilled the substantive requirement to be eligible for a Patent, based on comparative documents of both relevant Patent and non-Patent documents. Within no later than 36 months from the
Substantive Examination Application filed, the Patent Examiner must decide whether to refuse or grant a Patent. An applicant whose patent application is refused may appeal to the Patent Appeal Commission, which may proceed to the Commercial Court until finally appeal to the Supreme Court. If the applicant receives a refusal, or any legal remedy he or she ends up with a rejection, then the invention becomes a public domain. Against a Patented Invention, the Director General of Intellectual Property (DJKI) shall immediately issue a Patent

Certificate. Submitting a Patent Application to some people may indeed involve a very long process and can not be said simply. Especially needed special ability to be able to arrange document of good Patent Specification. It is therefore highly recommended for prospective applicants of Patent especially for those who have not experienced to obtain professional assistance from Registered HKI Consultant.

A patent shall be granted for a period of 20 (twenty) years from the filing date and not renewable. The start and end dates of the Patent shall be recorded and announced through electronic and / or nonelectronic media.[10] Simple patents are granted for a period of 10 (ten) years from the Filing Date and can not be extended. The starting and ending dates of a simple Patent shall be recorded and announced through electronic and / or non-electronic media. Most of the world's Patent laws provide an opportunity for other parties to control the process of filing a Patent application.

The Patent Holder or Licensee shall be entitled to file a indemnification to the Commercial Court against any person who knowingly and without right commits acts as referred to in Article 19 paragraph (1). The claim of indemnity filed against the acts referred to in paragraph (1) shall only be accepted if the product or process is proven to be made by using a Patented Invention. 
Any person without the Patent Holder's approval is prohibited: 1). In the case of Patent-products: make, use, sell, import, rent, deliver, and / or provide for sale, lease or delivery of Patented products; and / or; 2) In the case of a process-Patent: using a Patented production process to produce goods or other actions as referred to in a letter.

Any Person who intentionally and without right performing acts as referred to in Article 160 for Patent shall be liable to a maximum imprisonment of 4 (four) years and / or a maximum fine of $\mathrm{Rp}$ $1,000,000,000.00$ (one billion rupiah).

Any Person who intentionally and without right commits acts as referred to in Article 160 for a simple patent shall be liable to a maximum imprisonment of 2 (two) years and / or a maximum fine of Rp500,000,000.00 (five hundred million rupiah).

Any person who violates the provisions referred to in Article 161 and / or Article 162, resulting in health and / or environmental disturbances, is punished with imprisonment of not more than 7 (seven) years and / or a maximum fine of Rp2,000,000,000.00 (two billion rupiah). Any person who violates the provisions referred to in Article 161 and / or Article 162 , resulting in human death, is punished with a maximum imprisonment of 10 (ten) years and / or a maximum fine of Rp3,500,000,000.00 (three billion five hundred million rupiah).

Any Person who knowingly and without right to divulge documents of a Confidential Application as referred to in Article 45 paragraph (1) shall be sentenced to a maximum imprisonment of 2 (two) years.

The criminal act as referred to in Article 161, Article 162, and Article 164 shall constitute offense of complaint. Article 166. In the case of may order that the goods resulting from the breach of such Patent be seized by the State for destruction. Software protection in the form of computer program in Indonesia currently there are differences of opinion, according to information from the Directorate General of Intellectual Property (DJKI) Indonesia, a software (software) can still be protected by Patent mechanism if the software (software) solve technical problems and relate to technology as well as existing Patent certificate protection from the country of origin.

Law No. 13 of 2016, Article 4 states that the invention does not include: aesthetic creations, schemes, rules and methods for engaging in activities involving mental, games and business, rules and methods containing only computer programs, presentations on information and findings in the form of: new uses for existing and / or known products and / or new forms of existing compounds which do not result in significant increases in efficacy and there are known chemical structural differences of the compounds. In the explanation of Article 4 letter $\mathrm{d}$, the meaning of "rules and methods containing only computer programs" is a computer program that contains only the program without character, technical effects, and problem solving but if the computer program has a character (instructions) has the technical effect and function to produce a tangible or intangible problem solving is a Patentable Invention. Examples of patentable Inventions may include: 1) Algorithms, ie effective methods expressed as limited circuits of well-defined instructions for computing a function. Starting from a start condition and initial input (possibly empty), the instructions describe a computation that, when executed, is processed through a finite set of welldefined set of conditions, which ultimately produces "output" and stops final conditionality. The transition from one condition to the next does not have to be deterministic; several algorithms, known as randomization algorithms using random inputs; 2) Encrypting information by 
encoding and decoding to randomize so that information can not be read by others.

If the interpretation of a contrario (according to the denial) takes place, it means that based on Article 4 of Law no. 13 of 2016 on Patents, means "rules and methods that not only contain computer programs "can be used as Patent objects. Where such computer Programs have characters (instructions) that have technical effects and functions to produce tangible or intangible problem solving are patentable Inventions.

Software, databases, methodologies and bioinformatics products can only be protected through the copyright regime, this is based on the provisions of Law no. 28 of 2014 concerning Copyright, Article 40 paragraph (1) that one of the works that can be protected is a computer program. A computer program is one type of software. A software (software) can still be protected by a Patent mechanism if the software related to the computer program can solve technical problems and related to technology and there is already patent protection from the country of origin. Law no. 13 of 2016, Article 4, the invention does not cover, among other things: rules and methods that contain only computer programs. Only bioinformatics hardware, examples of potentially patented array technology in Indonesia. In addition,

bioinformatics (information) methodologies and products (information) can be protected through a trade secret regime because it is a valuable information that can be used to run a business, provided that the information is kept confidential by the owner. This is set forth in the provisions of Article 1 point 1: "Trade Secrets are information that is unknown to the public in the field of technology and / or business, has economic value as it is useful in business activities, and kept confidential by the owner of Trade Secret." Article 2: The scope of protection of the Trade Secret includes the method of production, method of processing, sales method, or other information in the field of technology and / or business which has economic value and is not known by the general public.

B. Regulation of Legal Protection Against Invention in the Field of Bioinformatics in the State of Singapore

Discovery is protected in Singapore under the Patent Act (Cap 221, 2002 Reved) (PA). This Act is based on the UK Patent Act 1977, although there are some important differences. Registration may be obtained in two ways: through (i) an application within the country submitted to the Registry of Patents Office at the Intellectual Property Office of Singapore ('IPOS'); or (ii) an international application submitted pursuant to a Patent Cooperation Agreement / Patent Cooperation Treaty, where the Registry Office acts as the Receiving Office of the application for registration.

A person who has previously applied for registration in a state of the Paris Convention / WTO, if he submits registration in Singapore within 12 months of the date of the application, he may claim priority rights. It is important to note that a resident of Singapore is considered committing an offense if the person concerned, without written permission from the Registry, filed or confirmed the filing of a Patent Application outside Singapore without first applying for the same invention in Singapore, at least two months prior to filing a Patent application outside Singapore an international scale application submitted pursuant to a Patent Cooperation Agreement, whereby the Registration Office acts as the Receiving Office of the application for registration.

A person who has previously applied for registration in a country of the Paris / World Trade Organization, if he submits a registration in Singapore within 12 months of the date of the application, he may claim priority rights. It is important to note that a resident of Singapore is considered committing an offense if the person concerned, without written permission from the Registry, filed or confirmed the 
filing of a Patent Application outside Singapore without first applying for the same invention in Singapore, at least two months prior to filing a Patent application outside of Singapore.

A patent may be awarded for the discovery of a product or process. The invention must meet the following conditions:

a. New;

The invention shall be deemed 'new' if it is not part of the State Of The Art which refers to all matters (whether product, process, product or process information or otherwise) at any time prior to the invention priority date available to the general public (both in Singapore or elsewhere) by explanation either in writing or orally, through use or otherwise. An item contained in the previous Patent application is also included. One need not be widely available to the general public in order to be part of the state of the art (Windsurfing International Inc. v Tabur Marine (GB) Ltd [1985] RPC 59). Whether or not an invention will be assessed from the date the application for registration is filed. If the applicant claims a priority right then the date of the application is the date of his application in a foreign country.

b. Inventive step;

An invention has an inventive step if the invention is not clearly known to those skilled. The skilled person does not necessarily have inventive skills but is deemed to have knowledge and practical experience for the type of work in which the invention will be used (Ng Kok Cheng v Chua Say Tiong [2001] 3 SLR 487). It can be a team of highly qualified researchers whose skills are commonly used in the relevant field (Optical Coating Laboratory v Pilkington case [1995] RPC 145 on page 156). To find out whether an invention is deemed to be clearly known or not, the court will take several actions, namely:
1. will first identify the inventive concepts covered by the Patent;

2. then ask an expert but not imaginative person in the field on the priority date of the Patent and ask him what has become common knowledge in that field;

3. identify what differences, if any, exist between such knowledge and the patentable invention; and last;

4. Consider whether, regardless of the invention, those differences are the steps that should be clearly known to those skilled in the art or whether they require all levels of invention.

Windsurfing International Inc. v Tabur Marine (GB) Ltd [1985] 59 on p. 73-74 applied in Merck \& Co. case. Inc. v Pharmaforte RPC is Singapore Pte Ltd [2000] 3 SLR 717. The fact that a simple invention does not mean it is clearly known (Peng Lian Trading Co. v Contour Optics Inc. case [2003] 2 SLR 560). Commercial success is a factor that can be taken into account in determining the element clearly known or not even if it is not conclusive ( $\mathrm{Ng}$ Kok Cheng v Chua Say Tiong's case [2001] 3 SLR 487).

c. Applicable in industry;

An invention shall be deemed applicable in the industry if it can be manufactured or used in any type of

industry, including agriculture. However, the method of treating the human or animal body through surgical or therapeutic action or a diagnosis practiced in the human or animal body is not considered to be applied in the industry although this does not preclude the patentability of the drug to be used in the treatment or diagnosis.

d. Publication or exploitation of the invention is generally not expected to encourage violent, immoral or antisocial behavior;

e. Behavior shall not be considered to be harsh, immoral or anti-social merely because such conduct is prohibited by any applicable law in Singapore. 
The patent of the invention is usually granted to the actual inventor of the invention, unless the patent shall be granted to another person or its substitute in accordance with a statute, rule of law, international treaty, international convention or applicable provisions of a treaty held with inventors prior to the invention being made.

A patent or a Patent application shall be personal property, therefore, a Patent and any right in or under such Patent may be transferred, pledged, licensed or granted in accordance with the law in the same way as any other personal property. The transfer of a Patent application or any right in Patent and any agreement relating to a Patent shall be declared void unless made in writing and signed by or on behalf of the parties involved in the invention.

Any person who claims to have acquired ownership of a Patent or a Patent application pursuant to a transaction,

instrument or event (collectively "transaction") shall declare the transaction to the Directorate General of Intellectual Property which, if it is not done, binds his right when dealing with the offender or a person obtaining rights that conflict with the invention. The recipient of an exclusive Patent license may have the same rights as the Patent owner in filing a Patent infringement proceeding.

An exclusive rights period shall be 20 years at the most from the date of application and shall become public domain after the expiration of that period. Within the Singapore Patent System the registered owner has the exclusive right to prevent other persons / owners from doing any of the below in connection with the patentable invention: if the invention is a product, make, sell, offer to sell, use or import products or store products whether for sale or otherwise; if the invention is a process, using the process or offering its use in Singapore if the person knows, or is clearly visible to ordinary people in the situation, that its use is without the consent of the owner is a Patent infringement and if the invention is a process, sells, offers to sell, use or import products obtained directly through the process or store products for sale or otherwise. Whether these rights have been violated or not depends on a comparison between a product or process that allegedly infringes a Patent with a Patent claim. Claims should be interpreted for the purpose (Catnic Components Ltd v Hill \& Smith Ltd [1982] RPC 183) and the following comparison approach has been used by the Singapore Court of Appeals in the case of Genelabs Diagnostics Pte Ltd v Pasteur \& anor Institute. [2001] 1 SLR 121: Does the variant have a material impact on how the invention works? If yes, that means the variant is outside the claim. Otherwise variants that have no material or obvious impact on the date of publication of the Patent for an expert reader in the field concerned. Otherwise, it means that the variant is outside the claim. If yes Whether the expert reader in this field has somehow understood from the content of the claim that the intended Patent is concerned is that genuine fulfillment with the essential meaning is a basic requirement of the invention. If yes, it means that the variant is outside the claim.

There are several actions that are considered not to be a violation of a Patent, that is: actions taken personally and not for commercial purposes; actions performed for experimental purposes related to the subject of the invention; and measures which include the immediate preparation of a drug for a person in accordance with a prescription or dentist or which includes the treatment of the drug.

The forms of remedies which may be determined by the Court in the proceedings of a breach shall include the determination of either a remedy or the calculation of the benefit of an order to surrender and / or destruction of goods in violation of a registered Patent and a statement that the Patent is valid and has been infringed. 


\section{CONCLUSION}

The regulations governing patent protection in Singapore in comparison with Indonesian law (Law No. 13 of 2016) bear a good resemblance to the subject of Patents, legal remedies, and other types of Patents. But if you look at the existing output Singapore is more efficient in terms of patents in the country. Formalities or Patent registration procedures in Indonesia prior to the coming into effect of Law no. 13 Year 2016 on Patents in taste is more complicated than in Singapore.

\section{REFERENCES}

[1] Muhammad Ahkam Subroto dan Suprapedi, Pengenalan HKI (Hak Kekayaan Intelektual) : Konsep Dasar Kekayaan Intelektual untuk Penumbuhan Inovasi, Jakarta: Indeks, 2008.

[2] Johnny Ibrahim, Teori \& Metodologi Penelitian Hukum Normatif, Malang: Bayumedia, 2011.

[3] Soerjono Soekanto, Penelitian Hukum Normatif Suatu Tinjauan Singkat, Jakarta: Rajawali Press, 1998.

[4] Suratman dan H. Phillips Dillah, Metode Penelitian Hukum, Bandung: Alfa Beta, 2012.

[5] Surakhmad Winarno, Metode dan Tekhnik dalam bukunya, Pengantar Penelitian Ilmiah Dasar Metode Tekhnik, Bandung: Tarsito,1994.

[6] H.B. Sutopo, Metodologi Penelitian Hukum Kualitatif Bagian II, Surakarta: UNS Press, 1998.

[7] Undang-Undang No. 13 Tahun 2013 Tentang Paten.

\section{BRIEF BIOGRAPHY}

Dr. Abdul Atsar, SH, MH Born In Karawang On February 16, 1981. In 2004 Graduated Obtained a Bachelor Degree in Law from the University of Singaperbangsa Karawang, 2013 Gained a Master Degree of Law from Graduate Program Master of Legal Studies Concentration Business Law University of Borobudur Jakarta with the title "With Praise ", And In 2016 Obtained Doctoral Degree of Law Science of Law Economics Concentration from Jayabaya University with Predicate Cumlaude. Currently Authors Live In Hamlet Gongcai II RT. 12 RW. 004 Teluk Bango Village Batujaya Karawang. Writer Office Address In FH Unsika Jl. H.S Ronggowaluyo East Jambe Bay Karawang. Extraordinary Lecturer In Faculty of Law University of Jakarta, STKIP Kusuma State Jakarta, Permanent Lecturer Faculty of Law University Singaperbangsa Karawang (From Year 2014 s.d Now). Writing the Produce: Juridical Sociological Aspects of the Impact of Sharia Cooperatives and Legal Protection in Its Implementation (2015); Influence of Investment and Local Government Policy in Investment Development in Kabupaten Karawang (2016); Prospect of Software Protection and Law Enforcement Arrangement of Computer Program in Indonesia (2016); Legal Protection of Traditional Knowledge in the Era of the Asean Economic Community (MEA) and Its Implications for the Indonesian Nation; Legal Protection Against UMKM Products through Brand Rights as One Efforts to Increase Creativity Based Competitiveness (2016); Government Policy on Marine Genetic Resources Protection in Indonesia in Order to Maintain and Manage Natural Marine Resources (2016); Legal Protection of Invention in the Field of Information and Communication Technology as One of the Efforts to Improve Public Welfare in Indonesia (2017); Comparison of Regulations Regarding Legal Protection of 
Invention in Information and Communication Technology Between Indonesia and Japan (2017). 